\title{
The Mechanisms of Plant Stress Mitigation by Kaolin-based Particle Films and Applications in Horticultural and Agricultural Crops
}

\author{
D. Michael Glenn ${ }^{1}$ \\ USDA-ARS-Appalachian Fruit Research Station, 2217 Wiltshire Road, Kearneysville, WV 25430 \\ Additional index words. heat stress, ultraviolet radiation, photosynthetically active radiation, \\ water stress, whole canopy photosynthesis
}

\begin{abstract}
Kaolin-based particle films have use in reducing insect, heat, photosynthetically active radiation (PAR), and ultraviolet radiation stress in plants resulting from the reflective nature of the particles. Particle films with a residue density of 1 to $4 \mathrm{~g} \cdot \mathrm{m}^{-2}$ have been evaluated in a range of crops and agricultural environments. The particle film is a general insect repellant resulting from the change in the plant's leaf/fruit texture but also because it changes the reflected light signature of the plant causing insect avoidance for many pests. The alteration of reflected light is the result of the ability of the particle film to reflect infrared (IR), $P A R$, and ultraviolet radiation. Reflection of IR can reduce canopy temperature as much as $5{ }^{\circ} \mathrm{C}$, which will reduce potential transpiration. The reduction of $P A R$ by the film at the leaf level is compensated in varying degrees by diffusion of $P A R$ into the interior of the canopy. Whole canopy photosynthesis can be increased by the combined particle film effects of reduced canopy temperature and increased diffusion of $P A R$ into the interior of the canopy. In apple, reducing fruit surface temperature, $P A R$, and ultraviolet is an effective means of reducing sunburn damage. The use of a reflective particle film is effective in mitigating environmental stress and has significant economic benefits in agricultural crops.
\end{abstract}

Kaolin-based particle films can reduce insect, heat, $P A R$, and ultraviolet stress in horticultural crops because of their ability to modify the microenvironment of the plant canopy as a result of the reflective nature of the particles. Particle films with a residue density of 1 to $4 \mathrm{~g} \cdot \mathrm{m}^{-2}$ leaf area have been evaluated in a range of crops and agricultural environments. The particle film is a general insect repellant resulting from the change in the plant's leaf/fruit texture but also because it changes the reflected light signature of the plant causing insect avoidance for many pests. A general review of particle film effects on insect pests and insect predators is presented in Glenn and Puterka (2005). Other key papers include: D'Aquino et al. (2011), Joubert et al. (2004), Lapointe et al. (2006), Leskey et al. (2010), Pascual et al. (2010), and Sackett et al. (2007).

The alteration of reflected light is the result of the ability of the particle film to reflect IR, $P A R$, and ultraviolet radiation (Glenn et al., 2002, 2008; Steiman et al., 2007). Reflection of IR can reduce canopy temperature as much as $5^{\circ} \mathrm{C}$, which will reduce potential transpiration (Glenn, 2009; Glenn et al., 2003; Jifon and Syvertsen, 2003); however, reducing canopy temperature can reduce heat stress and increase water use resulting in reduced water use efficiency and increased productivity (Glenn, 2010).

The reduction of $P A R$ by the film at the leaf level is compensated in varying degrees

Received for publication 5 Dec. 2011. Accepted for publication 17 Jan. 2012.

This paper was part of the colloquium, "Emerging Techniques to Evaluate and Mitigate Crop Environmental Stress in a Changing Climate" held 28 Sept. 2011 at the ASHS Conference, Waikoloa, HI, and sponsored by the Environmental Stress Physiology (STRS) Working Group.

${ }^{1}$ To whom reprint requests should be addressed; e-mail michael.glenn@ars.usda.gov. by diffusion of PAR into the interior of the canopy (Glenn and Puterka, 2007; Rosati et al., 2007; Wünsche et al., 2004). Whole canopy photosynthesis can be increased by the combination of reduced canopy temperature and increased interior canopy light (Glenn, 2009, 2010; Glenn et al., 2003).

In apple, reducing fruit surface temperature, $P A R$, and ultraviolet is an effective means of reducing sunburn damage in apple (Aly et al., 2010; Glenn et al., 2002, 2008; LeGrange et al., 2004; Wand et al., 2006) and other specialty crops including pomegranate (Melgarejo et al., 2004; Weerakkody et al., 2010) and tomato (Pace et al., 2007; Saavedra et al., 2006).

The particle film can improve apple fruit color in some regions (Aly et al., 2010; Garcia et al., 2003; Glenn, 2009; Glenn and Puterka, 2007; Glenn et al., 2001, 2005; Wand et al., 2006). However, there are instances of reduced apple color development (Gindaba and Wand, 2005; Schupp et al., 2002).

The use of a reflective particle film is effective in mitigating environmental stress and has significant economic benefits in agricultural crops. Glenn (2009) demonstrated in a 10-year study that fruit mass of kaolin-treated

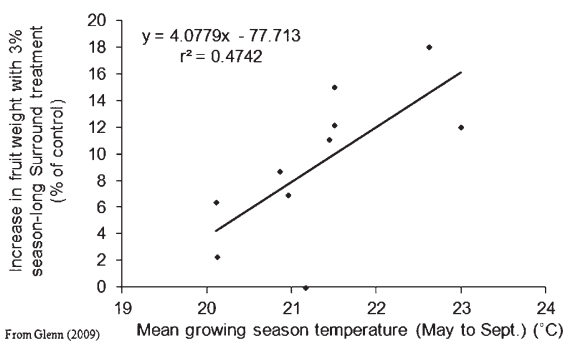

Fig. 1. Relationship of the increase in fruit weight with 3\% season-long Surround treatments (expressed as a percentage of the untreated control) to growing season temperature (19982007). apples was greater than the untreated fruit in 9 of 10 years and that the magnitude of the treatment response increased with increasing growing season temperature (Fig. 1). These data suggest that growing season temperatures above $20^{\circ} \mathrm{C}$ can potentially reduce fruit size, but the use of the reflective particle film can mitigate that effect. Management tools, including kaolin-based particle films, will be needed to mitigate increasing growing season temperatures associated with global climate change.

\section{Literature Cited}

Aly, M., N.A. El-Megeed, and R.M. Awad. 2010. Reflective particle films affect on sunburn, yield, mineral composition and fruit maturity of 'Anna' apple (Malus domestica) trees. Res. J. Agr. Biol. Sci. 6:84-92.

D'Aquino, S.D., A. Cocco, S. Ortu, and M. Schirra. 2011. Effects of kaolin-based particle film to control Ceratitis capitata (Diptera: Tephritidae) infestations and postharvest decay in citrus and stone fruit. Crop Prot. 30:10791086.

Del Saavedra, R.G., M.G. Escaff, and J.V. Hernandez. 2006. Kaolin effects in processing tomato production in Chile. Acta Hort. 724:191 198.

Garcia, M.E., L.P. Berkett, and T. Bradshaw. 2003. Does Surround have non-target impacts on New England orchards? In: Bramlage, W. (ed.). Proc. New England Fruit Meetings 2002-2003. 108-109:35-39.

Gindaba, J. and S.J.E. Wand. 2005. Comparative effects of evaporative cooling, kaolin particle film and shade net on sunburn and fruit quality in apples. HortScience 40:592596.

Glenn, D.M. 2009. Particle film mechanisms of action that reduce the effect of environmental stress in 'Empire' apple. J. Amer. Soc. Hort. Sci. 134:314-321.

Glenn, D.M. 2010. Canopy gas exchange and water use efficiency of 'Empire' apple in response to particle film, irrigation, and microclimatic factors. J. Amer. Soc. Hort. Sci. 135:25-32. 
Glenn, D.M., S. Drake, J.A. Abbott, G.J. Puterka, and P. Gundrum. 2005. Season and cultivar influence the fruit quality response of apple cultivars to particle film treatments. HortTechnology 15:249-253.

Glenn, D.M., E. Erez, G.J. Puterka, and P. Gundrum. 2003. Particle films affect carbon assimilation and yield in 'Empire' apple. J. Amer. Soc. Hort. Sci. 128:356-362.

Glenn, D.M., E. Prado, A. Erez, J. McFerson, and G.J. Puterka. 2002. A reflective processedkaolin particle film affects fruit temperature, radiation reflection and solar injury in apple. J. Amer. Soc. Hort. Sci. 127:188-193.

Glenn, D.M. and G.J. Puterka. 2005. Particle films: A new technology for agriculture. Hort. Rev. 31:1-44.

Glenn, D.M. and G.J. Puterka. 2007. The use of plastic films and sprayable reflective particle films to increase light penetration in apple canopies and improve apple color and weight. HortScience 42:91-96.

Glenn, D.M., G.J. Puterka, S.R. Drake, T.R. Unruh, A.L. Knight, P. Baherle, E. Prado, and T.A. Baugher. 2001. Particle film application influences apple leaf physiology, fruit yield, and fruit quality. J. Amer. Soc. Hort. Sci. 126:175-181.

Glenn, D.M., J. Wünsche, I. McIvor, R. Nissen, and A. George. 2008. Ultraviolet radiation effects on fruit surface respiration and chlorophyll fluorescence. J. Hortic. Sci. Biotechnol. 83:43-50.

Jifon, J.L. and J.P. Syvertsen. 2003. Kaolin particle film applications can increase photosynthesis and water use efficiency of 'Ruby Red' grapefruit leaves. J. Amer. Soc. Hort. Sci. 128:107-112.

Joubert, P.H., T. Grové, M.S. De Beer, and W.P. Steyn. 2004. Evaluation of kaolin (SURROUND WP) in an IPM program on mangoes in South Africa. Acta Hort. 645:493-499.

Lapointe, S.L., C.L. Mckenzie, and D.G. Hall. 2006. Reduced oviposition by Diaprepes abbreviatus (Coleoptera: Curculionidae) and growth enhancement of citrus by Surround particle film. J. Econ. Entomol. 99:109116.

Le Grange, M., S.J.E. Wand, and K.I. Theron. 2004. Effect of kaolin applications on apple fruit quality and gas exchange of apple leaves. Acta Hort. 636:545-550.

Leskey, T.C., S.E. Wright, D.M. Glenn, and G.J. Puterka. 2010. Effect of Surround WP on behavior and mortality of apple maggot (Diptera: Tephritidae). J. Econ. Entomol. 103: 394-401.

Melgarejo, P., J.J. Martinez, F. Hernandez, R. Martinez-Font, P. Barrows, and A. Erez. 2004. Kaolin treatment to reduce pomegranate sunburn. Sci. Hort. 100:349-353.

Pace, B., F. Boari, V. Cantore, L. Leo, S. Vanadia, E. De Palma, and N. Phillips. 2007. Effect of particle film technology on temperature, yield and quality of processing tomato. Acta Hort. 758:287-293.

Pascual, S., G. Cobos, and E. Seris. 2010. Effects of processed kaolin on pests and non-target arthropods in a Spanish olive grove. J. Pest Sci. $83: 121-133$
Rosati, A., S.G. Metcalf, R.P. Buchner, A.E. Fulton, and B.D. Lampinen. 2007. Effects of kaolin application on light absorption and distribution, radiation use efficiency and photosynthesis of almond and walnut canopies. Ann. Bot. (Lond.) 99:255-263.

Sackett, T.E., C.M. Buddle, and C. Vincent. 2007. Effects of kaolin on the composition of generalist predator assemblages and parasitism of Choristoneura rosaceana (Lep., Tortricidae) in apple orchards. J. Appl. Entomol. 131:478-485.

Schupp, J.R., E. Fallahi, and I.J. Chun. 2002. Effect of particle film on fruit sunburn, maturity and quality of 'Fuji' and 'Honeycrisp' apples. HortTechnology 12:87-90.

Steiman, S.R., H.C. Bittenbender, and T.W. Idol. 2007. Analysis of kaolin particle film use and its application on coffee. HortScience 42:16051608.

Wand, S.J.E., K.I. Theron, J. Ackerman, and S.J.S. Marais. 2006. Harvest and post-harvest apple fruit quality following applications of kaolin particle film in South African orchards. Sci. Hort. 107:271-276.

Weerakkody, P., J. Jobling, M. Magdalena, V. Infante, and G. Rogers. 2010. The effect of maturity, sunburn and the application of sunscreens on the internal and external qualities of pomegranate fruit grown in Australia. Sci. Hort. 124:57-61.

Wünsche, J.N., L. Lombardini, and D.H. Greer. 2004. 'Surround' particle film applicationsEffects on whole canopy. Acta Hort. 636:565571. 